\title{
Study on the Framework of the Management Platform for CPA Audit
}

\author{
Xu LIU \\ of School of Finance and Economics \\ Guangdong University of Foreign Studies \\ Guangzhou, China \\ liuxu701@21cn.com
}

\author{
Shijian LIN \\ of School of Finance and Economics \\ Guangdong University of Foreign Studies \\ Guangzhou, China \\ linsj2007@hotmail.com
}

\begin{abstract}
With the wide application of information technology in management, Audit Informationization has been the inevitable evolution trend of the CPA industry. Based on the features and needs of the CPA industry, we provide the Management Platform for CPA Audit, an ERP system. The Management Platform consists of four sections - Customer Management Center, Project Management Center, Audit Operations Center and Quality Control Center. Based on the framework of the Management Platform, we design operation process and components of the four Centers. The Management Platform can improve the operating quality and core competence of CPAs, and can make audit process more effective, safer, more efficient and more economical.
\end{abstract}

Keywords-Audit Software; ERP; Framework; Operation Process; Component

\section{INTRODUCTION}

With the wide application of information technology in management, Audit Informationization has been the inevitable evolution trend of the CPA industry. Rapid and Accurate, information technology can make audit process more effective and more efficient, and enhance the core competence of CPAs. In 2009, Ministry of Finance advocated that in about five years, we shall fully improve the level of information technologies used in the internal management of accounting firms, and basically realize the target that middle- and large-sized accounting firms conduct the audit of financial reports, audit of internal controls and provision of other relevant services by information technology means. Therefore, Audit Informationization is not only about technologies, but also about the development strategies of the CPA industry.

Audit Informationization can promote the development of the CPA industry greatly. And to achieve the objectives of Audit Informationization, we shall analyze the business characteristics of CPA Audit. First, CPA Audit services are operated as projects. To ensure that the services are effective and efficient, CPAs should integrate the whole process of the services. Second, team members of CPA Audit services usually perform tasks separately in different places. Therefore, it is crucial to collaborate and share information efficiently. Third, CPAs usually process great amounts of data in CPA Audit services. Without information technology means, audit process would be much less efficient. Fourth, quality of service is the lifeline of CPAs. CPAs should perform review to ensure quality in the services.

Currently, there are still some problems with the implementation of Audit Informationization. In many accounting firms, all the personnel are equipped with computers, but they operate audit services only with simple computer tools (such as Excel and Word), not with specialized audit software. Even some specialized audit software are used, these software are transaction processing systems which simply perform tasks based on the existing audit process. They do not improve management under the principles of risk based audit, so that they can not enhance the core competence of CPAs. Therefore, it is necessary to develop audit software in accordance with modern management concepts, based on the features and needs of the CPA industry.

\section{DEFECTS IN DOMESTIC AUDIT SOFTWARE}

As mentioned above, Audit Informationization has been the inevitable evolution trend of the CPA industry. Audit software can make audit process more effective and more efficient, and enhance the core competence of CPAs.

However, there are still some defects in the existing audit software. These defects are as follows:

First, lacking analysis capabilities. Risk assessment is extremely important in risk based audit. But most existing audit software are deficient in capabilities of analysis and risk assessment. They only perform common analysis and simple calculations of financial ratios.

Second, outdated design. With the development of management science, the application of project management and quality management has been the evolution trend of business management. But most existing audit software are deficient in capabilities of planning, organizing, coordinating, supervising, controlling and evaluating in audit process, neglecting process control and quality management. They simply emphasize on the performance of substantive testing.

The defects mentioned above have seriously restricted the advance of Audit Informationization and the development of the CPA industry. Therefore, based on full research, we provide an ERP system for the management of accounting firms, hoping to further promote the development of the CPA industry. 


\section{FRAMEWORK OF THE MANAGEMENT PLATFORM FOR CPA AUDIT}

Based on extensive research and demonstration, we provide the Management Platform for CPA Audit, an ERP system. The framework of the Platform is as below:

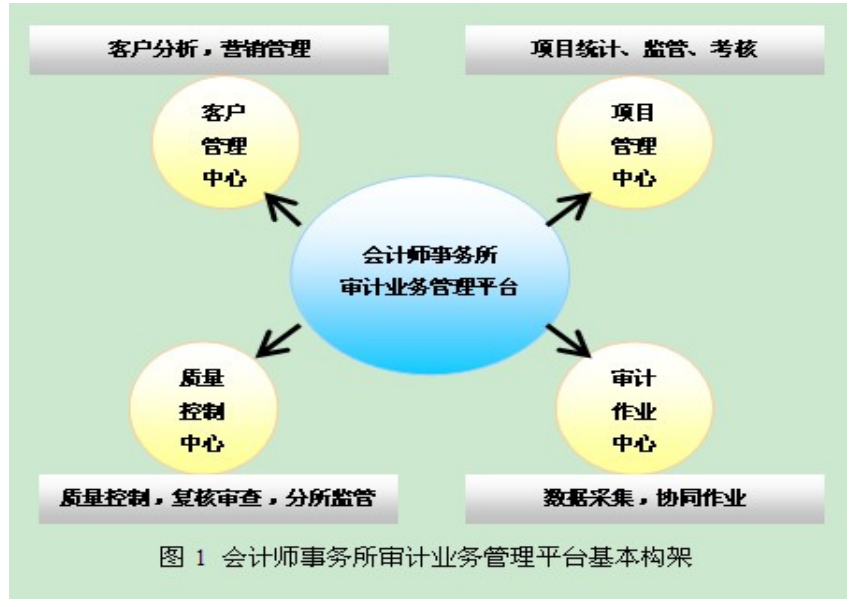

Figure 1. Framework of the Management Platform for CPA Audit

The Management Platform for CPA Audit is designed to combine audit process with advanced management theories, providing an integrated management platform for CPAs. The Platform can integrate and optimize the management and operation processes in accounting firms, so it can improve the operating quality and core competence of CPAs, and can make audit process more effective, safer, more efficient and more economical.

The Management Platform for CPA Audit consists of four sections - Customer Management Center, Project Management Center, Audit Operations Center and Quality Control Center. Customer Management Center can integrate customer information and control marketing process with customeroriented principle, helping improve marketing efficiency and reduce business risks. Project Management Center uses theories of Systems Science to plan, organize, coordinate and control resources involved in audit projects. Audit Operations Center can integrate and optimize audit process with information technology, establishing standard processes in accordance with the requirements of China Standards on Auditing. Quality Control Center is designed to integrate review process, ensuring that business process in accounting firms is in accordance with quality requirements.

The operation process of the Management Platform for CPA Audit is as below:

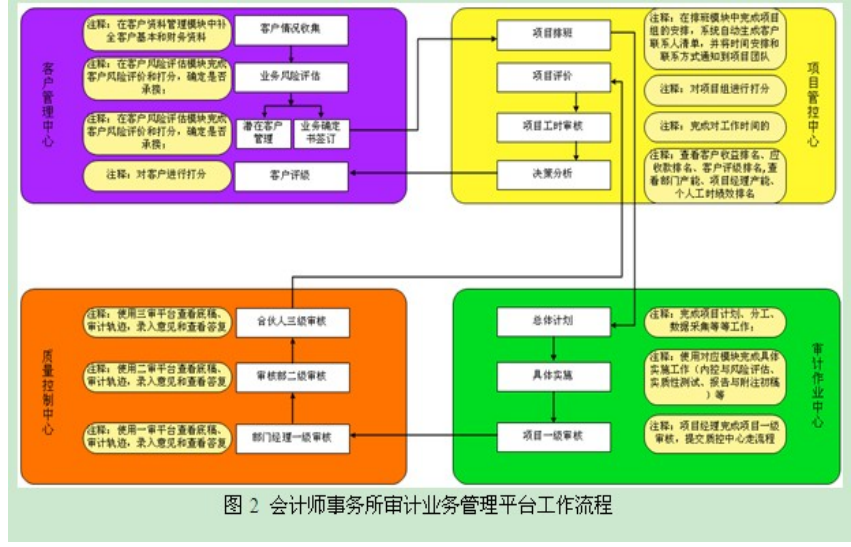

Figure 2. Operation process of the Management Platform for CPA Audit

\section{COMPONENTS OF THE MANAGEMENT PLATFORM FOR CPA AUDIT}

As mentioned above, the Management Platform for CPA Audit consists of four centers - Customer Management Center, Project Management Center, Audit Operations Center and Quality Control Center. The operation process and components of the four Centers are designed in accordance with the business process in accounting firms.

\section{A. Customer management center}

In the initial operations of CPA Audit, accounting firms need to investigate client condition, assess business risks, evaluate their own professional competence and prepare audit engagement letters. Customer Management Center should be able to integrate marketing process and control all information in marketing process. Therefore, components of client information collection, business risk assessment, potential client management, contract management and client ratings should be included in Customer Management Center. With these components, Customer Management Center can collect marketing information dynamically and assess business risks to provide information for decision making. The Center can also help CPAs create client profiles, contact clients, prepare audit engagement letters and manage payment matters, so that accounting firms can keep track of marketing condition. After business is accepted, the Center will transmit client information to Project Management Center.

The operation process of Customer Management Center is as below:

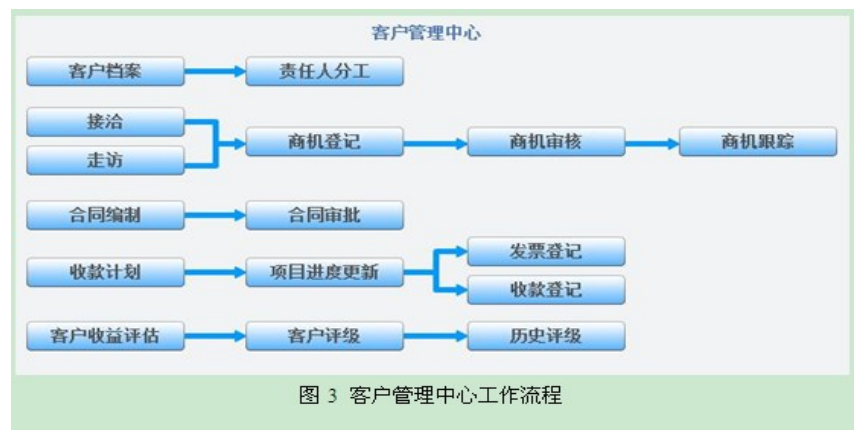

Figure 3. Operation process of Customer Management Center 


\section{B. Project management center}

After accepting business, accounting firms need to make business plans, organize teams, assign tasks, monitor progress and evaluate performance. Project Management Center should be able to allocate resources reasonably to improve efficiency. Therefore, components of scheduling, evaluation, working hours management and analysis should be included in Project Management Center. With these components, Project Management Center can approve projects, make schedules, manage working hours, evaluate performance, make incentive plans and analyze productivity, so that accounting firms can achieve the integration of project management.

The operation process of Project Management Center is as below:

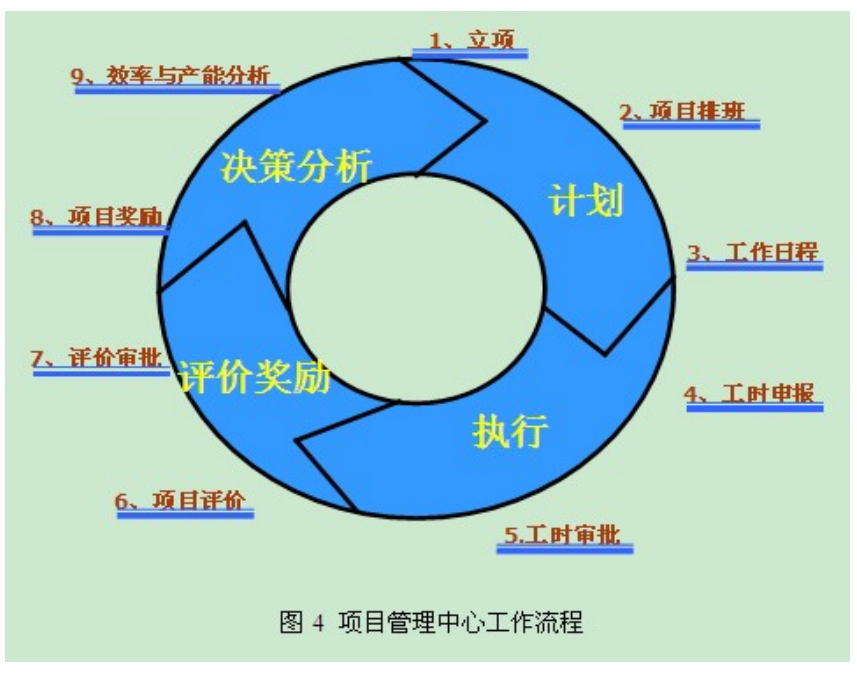

Figure 4. Operation process of Project Management Center

\section{Audit operations center}

When performing audits, CPAs need to make audit plans, understand the audited entity and its environment and assess the risks of material misstatement, make internal control testing and substantive testing and prepare auditor's reports. Audit Operations Center should be able to integrate and optimize audit process according to the requirements of China Standards on Auditing. Therefore, components of audit planning, performing and reviewing should be included in Audit Operations Center. With these components, Audit Operations Center can collect and verify data, make audit plans and set materiality levels. The Center can also help CPAs assess the risks of material misstatement, make internal control testing and substantive testing and prepare working papers and auditor's reports. Project managers can perform preliminary review in Audit Operations Center. below:

The operation process of Audit Operations Center is as

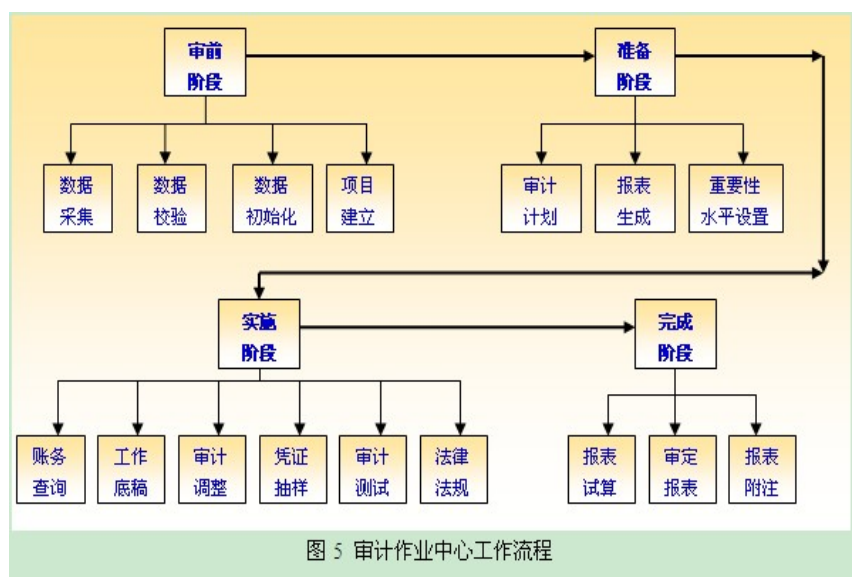

Figure 5. Operation process of Audit Operations Center

\section{Quality control center}

When conducting audits, CPAs need to perform review several times according to China Standards on Auditing. Quality Control Center should be able to integrate the process of review to improve efficiency and effectiveness. Therefore, components of review at each stage should be included in Quality Control Center. CPAs can review working papers, enter comments and view feedback in the Center. The Center can also list project results, report major issues and perform statistical analysis. below:

The operation process of Quality Control Center is as

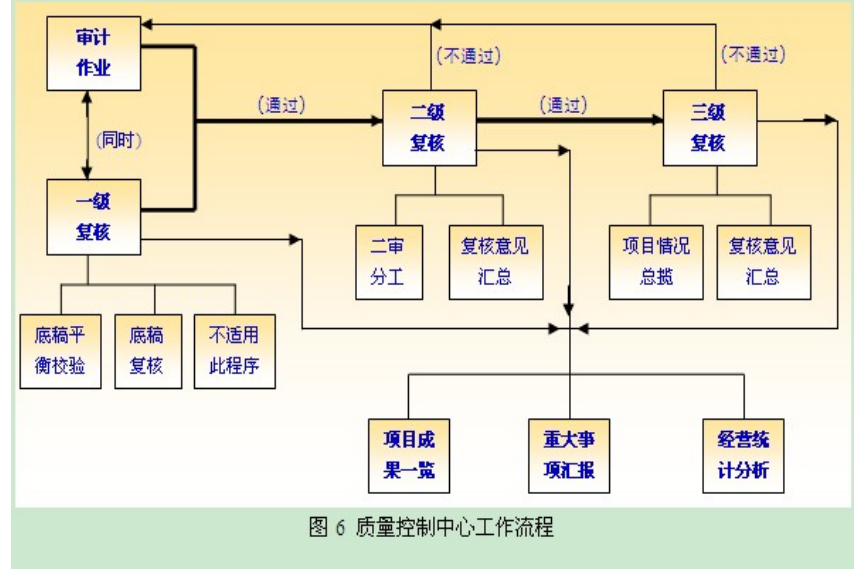

Figure 6. Operation process of Quality Control Center

\section{CONCLUSION}

In this paper, we discuss the problems with the implementation of Audit Informationization, believing that they are due to backward in the development of audit software. Then we provide the Management Platform for CPA Audit, an ERP system. The Platform can integrate and optimize business process in accounting firms and improve the operating quality and core competence of CPAs. We hope that this paper will provide useful reference for other research on Audit Informationization. 


\section{REFERENCES}

[1] Chinese Institute of Certified Public Accountants, China Standards on Auditing, Review, Other Assurance, Related Services and Quality Control, Beijing: Economic Science Press, 2006 (In Chinese).

[2] Xu Liu, Research on Integrated Information Platform for CPA Audit, Beijing: Economic Science Press, 2009 (In Chinese).

[3] Jun Xie, and Hongfei Li, Improvement of the functions of audit software under the new standards on audit. Finance and Accounting Monthly, pp.67-68, Issue No.33, 2008 (In Chinese).
[4] Guiyun Yue, On the development of audit software. Commercial Accounting, pp.48, Issue No.9, 2010 (In Chinese).

[5] Qinhong Wu, Study on Audit Informationization and its framework. China Management Informationization, pp.88-90, Issue No.12, 2007 (In Chinese).

[6] Xuefeng Wang, The development of Audit Informationization. Inner Mongolia Science Technology and Economy, pp.80-82 Issue No.3, 2009 (In Chinese). 